\title{
KERAHIMAN ALLAH DI TENGAH KELUARGA KRISTIANI
}

\author{
Oleh: \\ Antonius Virdei Eresto Gaudiawan \\ STKIP Widya Yuwana
}

\begin{abstract}
Pope Francis promulgate Iubilaeum Extraordinarium Misericordiae. In the context of that jubilee, it is needed to reflect on the Christian family. How to make God's Mercy radiat in the midst of Christian families through their problems. Christian families need God's Mercy because nowadays, there are so much wounds exist in the families. We hope every Christian families receives God's Mercy to encourage their lifes. Every people are called to show God's Mercy in their own families. The research was made with qualitative research methods by reflecting the fundamentals of church faith such as the Scriptures and Church teachings. Furthermore, from the basis of this faith, the author will try to explore and reflect on the problem of the Christian family today. Next, look for and reflect on how God's merciful face is present in the midst of Christian families, now and here. Every family member needs to experience and realize. Forgiveness rooms are wide open for each family member. Grace rooms are open to every member of the Christian family who is involved.
\end{abstract}

Keywords: God's Mercy, Jubilee, Christian family

\section{PENDAHULUAN}

Sejak 8 Desember 2015 sampai dengan 20 November 2016, Paus Fransiskus mempromulgasikan Yubelium Kerahiman Ilahi. Sebuah peristiwa berahmat yang sungguh dibutuhkan untuk pribadi-pribadi dewasa ini. Sebuah kasih yang begitu nyata dan membawa perubahan bagi setiap pribadi. Dalam rangka Yubelium Kerahiman itulah, perlu direfleksikan kembali dan diperjuangkan usaha dan cara yang dengannya wajah kerahiman menjadi nyata. Salah satu tempat di mana kerahiman Allah sebaiknya muncul adalah di tengah keluarga Kristiani.

Keluarga Kristiani membutuhkan kerahiman Allah karena sekarang ini tidak jarang ditemukan banyak luka-luka yang ada di tengah-tengah keluarga. Ada banyak kesakitan yang dialami oleh keluarga-kelurga Kristiani. Ada banyak problematika yang menerpa keluarga-keluarga modern saat ini. Di tengah berbagai problematika yang sering terjadi tersebut, pertanyaan mendasar yang harus direfleksikan bersama sebagai orang beriman adalah bagaimana Wajah kerahiman Allah itu bisa bersinar dan melindungi keluarga-keluarga Kristiani. 
Dalam kerahiman Allah itulah pengampunan dan pertobatan justru akan menjadi nyata.

Penelitian ini dibuat dengan metode penelitian kualitatif dengan merefleksikan dasar-dasar iman gereja seperti Kitab Suci dan ajaran Gereja. Selanjutnya, dari dasari iman tersebut penulis akan mencoba menggali dan merefleksikan problematik keluarga Kristiani dewasa ini. Selanjutnya, dicari dan direfleksikan bagaimana wajah kerahiman Allah itu hadir di tengah keluarga Kristiani, kini dan di sini.

\section{KERAHIMAN ALLAH}

Bagian ini secara khusus ingin membahas tentang makna, konsep dan perwujudan wajah kerahiman Allah dalam hidup sehari-hari. Pemahaman ini akan membantu dalam menemukan refleksi teologis bagi keluarga Kristiani.

\subsection{Kerahiman Allah dalam Perjanjian Lama}

Pada bagian ini, dibahas secara singkat beberapa teks Perjanjian Lama yang berbicara tentang kerahiman. Tidak semua teks dibahas hanya diambil beberapa teks yang dipandang kunci untuk berbicara tentang kerahiman Allah.

"Roh Tuhan Allah ada padaku, oleh karena Tuhan telah mengurapi aku; Ia telah mengutus aku untuk menyampaikan kabar baik kepada orang-orang sengsara, dan merawat orangorang yang remuk hati, untuk memberikan pembebasan kepada orang-orang tawanan, dan kepada orang-orang yang terkurung kelepasan dari penjara, untuk memberitakan tahun rahmat Tuhan dan hari pembalasan Allah kita, untuk menghibur semua orang berkabung.” (Yes 61:1-2)

Bagian ini diperkirakan adalah berita tentang panggilan seorang nabi. Berita ini mengingatkan tentang panggilan Hamba Yahwe. Berita panggilan ini berita penghiburan. Di sini, diwartakan kerahiman Allah kepada orang yang sengsara, tertawan, terkurung. Kerahiman adalah warta pembebasan.

"Bukan! Berpuasa yang Kukehendaki, ialah supaya engkau membuka belenggu-belenggu kelaliman, dan melepaskan talitali kuk, supaya engkau memerdekakan orang yang teraniaya dan mematahkan setiap kuk, supaya engkau memecah-mecah rotimu bagi orang yang lapar dan membawa ke rumahmu orang miskin yang tak punya rumah, dan apabila engkau melihat orang telanjang, supaya engkau memberi dia pakaian dan tidak menyembunyikan diri terhadap saudaramu sendiri!” (Yes 58:6-7)

Dari teks di atas, kerahiman bukan pertama-tama berpuasa atau amal saleh. Kerahiman memiliki dua makna. Pertama, kerahiman adalah melepaskan, 
membebaskan, memerdekakan, dan mematahkan beban. Rahmat pelepasan membawa pada pengharapan dalam iman. Kedua, kerahiman juga berarti berbagi. Dengan berbagi, akan terjadi kesejahteraaan dan keselamatan bersama. Berbagi terhadap orang-orang yang ada di sekitar.

Dalam rangka kerahiman, bukan pertama-tama kurban bakaran yang dibutuhkan oleh Allah. Kasih setia dan pengenalan akan Allah lebih dibutuhkan. Kasih setia adalah kehendak dari dalam diri setiap pribadi untuk hanya mengandalkan hidup kepada Allah. Mengandalkan hidup berarti mendekatkan diri kepada Allah dan melakukan apa yang sejatinya dikehendaki oleh Allah. Ketaatan kepada Allah ini bukan pertama-tama ketaatan pada aturan yang dibuat oleh manusia untuk diterapkan pada diri Allah. Ketaatan ini adalah kesetiaan pada Allah yang maharahim.

Menjadi jelas bahwa pribadi yang memiliki kasih setia pada Allah dan memiliki pengenalan akan Allah tentu bersikap yang lain daripada manusia biasa. Di sana akan terdapat sikap rendah hati, kejujuran, kelemah-lembutan, kesederhanaan, kedamaian, kebahagiaan dan sebagainya. Hal inilah yang perlu dikembangkan dalam kerangka mengembangkan dan menghidupkan kerahiman Ilahi.

"Sembunyikanlah wajah-Mu terhadap dosaku, hapuskanlah segala kesalahanku!Jadikanah hatiku tahir, ya Allah, dan perbaharuilah batinku dengan roh yang teguh!...Maka aku akan mengajarkan jalan-Mu kepada orang-orang yang melakukan pelanggaran, supaya orang-orang berdosa berbalik kepadaMu" (Mzm 51:11-12, 15).

Wajah kerahiman adalah wajah pengampunan. Pengampunan terhadap dosa, pengampunan terhadap tindakan salah, dan pendamaian. Di dalam pengampunan itulah justru orang berdosa akan berbalik. Pengampunan menumbuhkan pertobatan, inilah salah satu bagian dari kenyataan hukum kasih yang tak terbantahkan.

\subsection{Kerahiman Allah dalam Perjanjian Baru}

Pada bagian ini, secara singkat akan direfleksikan teks-teks Perjanjian Baru yang berbicara tentang kerahiman Allah. Dipilih teks-teks kunci yang dirasa penting dan berbicara tentang kerahiman Allah.

"Barangsiapa tidak mengasihi, ia tidak mengenal Allah, sebab Allah adalah kasih” ... "Kita telah mengenal dan telah percaya akan kasih Allah kepada kita. Allah adalah kasih, dan barangsiapa tetap berada di dalam kasih, ia tetap berada di dalam Allah dan Allah di dalam dia” (1 Yoh 4:8, 16). 
Wajah kerahiman adalah wajah kasih. Paus Benediktus menegaskan dalam ensiklik Deus Caritas Est bahwa Allah adalah kasih. Oleh karena itu, setiap orang beriman memiliki tuntutan untuk hidup dalam kasih itu. Kasih menjadi cara hidup orang yang berada di dalam jalan Allah.

Teks Lukas bab 15 berbicara tentang perumpamaan domba yang hilang, dirham yang hilang dan tentang anak yang hilang. Teks-teks tersebut sangat sering didengarkan oleh umat beriman. Beberapa hal bisa dimaknai dari perumpamaanperumpamaan tersebut. Pertama, kerahiman berarti mencari yang hilang dan atau tersesat. Wajah kerahiman adalah wajah yang merangkul dan mengajak kembali. Wajah ini bisa dilihat dalam perumpamaan domba dan dirham yang hilang. Gembala dan wanita itu mencari domba dan dirhamnya. Sampai ketemu! Bukan hanya mencari dengan biasa-biasa saja. Ada sukacita yang melimpah ketika domba dan dirham diketemukan, itulah wajah kerahiman Allah yang senantiasa mencari yang tersesat dan hilang tidak ada satupun yang ditinggalkan. Kedua, wajah kerahiman adalah penerimaan kembali tanpa memperhitungkan apapun kesalahan yang telah terjadi. Demikianlah Bapa yang murah hati telah menerima anak bungsu yang telah durhaka terhadap Bapa dan hidup dalam pesta pora dan kemabukan. Tanpa perhitungan dan tanpa kompromi. Hanya ada kemurahan hati.

Matius 18:22 menulis: "Aku berkata kepadamu: Bukan sampai tujuh kali, melainkan sampai tujuh puluh kali tujuh kali”. Pengampunan diberikan bukan hanya tujuh kali saja, pengampunan diberikan tanpa batas. Selalu ada waktu dan ruang untuk pengampunan. Itulah tuntutan yang harus dikembangkan untuk setiap orang beriman. Mengampuni sampai tak terhitung, inilah wajah kerahiman Allah.

Paulus juga menulis: "Apabila kamu menjadi marah, janganlah kamu berbuat dosa: janganlah matahari terbenam, sebelum padam amarahmu” (Ef 4:26). Wajah kerahiman adalah wajah yang mudah lupa, mudah lupa akan kemarahan, mudah meredakan kemarahan. Kemarahan tidak dipegang terus menerus, tidak ada kebencian yang terlalu lama, tidak ada kedengkian yang terlalu lama. Semuanya berjalan begitu cepat karena kerahiman.

\subsection{Yesus Wajah Kerahiman Allah}

Selanjutnya, pandangan diarahkan kepada pribadi Yesus sendiri yang adalah wajah kerahiman Allah itu sendiri. Dengan merefleksikan karya penyelamatan Yesus, bisa ditemukan berbagai wajah kerahiman Allah itu sendiri.

Hati Yesus adalah hati yang mudah tergerak oleh belas-kasihan. Ketika orang sakit berbondong-bondong mengikuti Yesus, hati-Nya tergerak untuk menyembuhkan. Wajah kerahiman adalah wajah belas kasih yang menyembuhkan. Ketika banyak orang mengalami lapar karena mengikuti kemana Yesus pergi, Yesus tergerak hatinya, Dia memberi makan lima ribu orang dengan 
menggandakan lima roti dan dua ikan dari seorang anak kecil. Wajah kerahiman adalah wajah belas kasih yang memuaskan dahaga dan lapar orang beriman.

Yesus senantiasa mengampuni dan menyembuhkan yang sakit. Dua hal ini tidak pernah lepas dari tindakan kasih Yesus. Pengampunan itulah yang menyembuhkan, sehingga mereka yang buta menjadi melihat, yang mati hidup lagi, yang kusta menjadi tahir, dan yang lumpuh bisa berjalan. Inilah wajah kerahiman Allah, wajah pengampunan yang menyembuhkan. Pengampunan yang tidak hanya menyembuhkan hati, tetapi juga membawa pada kesembuhan badan.

Yesus adalah pemimpin yang melayani. KasihNya membuat Dia mau menjadi yang paling rendah di antara manusia. TindakanNya membasuh kaki para rasul yang sering dikenangkan kembali pada hari raya Kamis Putih adalah wajah kerahiman yang berani merendahkan diri, melayani dan mengasihi. Tindakan khas Yesus itulah yang tentu harus diikuti oleh umat beriman untuk menampakkan wajah kerahiman Allah. Inilah kasih yang begitu agung, melayani menjadi salah satu titik kunci dalam mewujudkan kerahiman Allah.

Puncak dari seluruh kerahiman Allah adalah peristiwa sengsara, wafat dan kebangkitan Yesus. Allah tidak pernah mau memandang derajatNya. Dia mengosongkan diri menjadi sama seperti manusia, bahkan menjadi manusia yang paling hina. Perendahan diriNya itulah yang menyebabkan Yesus akhirnya dipermuliakan oleh Bapa.Demikian diungkapkan oleh Paulus dalam himne Kristologisnya. Berkat sengsara, wafat dan kebangkitan Kristus itulah kuasa maut telah dikalahkan. Sekali untuk selama-lamanya wafat dan kebangkitan itu mematahkan kuasa maut atas diri manusia. Akhirnya, kembalilah manusia bisa berelasi kembali dengan Bapa. Berkaca dari pemberian diri yang total tersebut, setiap umat beriman diundang untuk memberikan dirinya bagi orang lain. Kasih kerahiman adalah memberikan diri bagi kebahagiaan orang lain. Wajah kerahiman adalah pemberiaan diri tanpa batas untuk orang lain.

Berkaca dari Kitab Suci baik Perjanjian Lama maupun Perjanjian Baru serta dengan melihat Yesus sebagai wajah kerahiman Allah, bolehlah disampaikan beberapa simpul berikut. Tentu simpul ini tidak bisa mencakup semua hal.

1. Kerahiman adalah warta pembebasan.

2. Kerahiman adalah berbagi.

3. Kerahiman adalah kasih setia pada Allah dan pengenalan akan Allah.

4. Kerahiman adalah pengampunan yang berlimpah dan akhirnya menyembuhkan.

5. Kerahiman adalah merangkul dan menerima kembali yang hilang.

6. Kerahiman adalah mencari yang tersesat.

7. Kerahiman adalah mudah lupa akankemarahan, kedengkian, kecemburuan dan sebagainya.

8. Kerahiman adalah hati yang tergerak oleh belas-kasihan. 
9. Kerahiman adalah kasih yang melayani.

10. Kerahiman adalah pemberian diri tanpa syarat apapun.

\section{PROBLEMATIKA KELUARGA KRISTIANI DEWASA INI}

Ada berbagai macam problematika yang dewasa ini dialami oleh keluargakeluarga Kristiani. Problematika tersebut tersebar mulai dari relasi antara suami dan istri, relasi antara orang tua dan anak, serta relasi antara keluarga inti dan keluarga besar. Masing-masing problematika membawa situasi dan dampaknya sendiri-sendiri.

\subsection{Problematika Relasi Suami Istri}

Problem ketidaksetiaan kadangkala terjadi dalam kehidupan suami istri. Ketidaksetiaan bisa disebabkan oleh berbagai macam faktor. Ada faktor dari internal ada juga faktor dari internal. Tidak jarang, ketidaksetiaan ini membawa dampak yang buruk bagi hidup perkawinan.Pada dasarnya, perkawinan adalah persekutuan dua pribadi yang berbeda. Berbeda dalam cara memandang dan menilai segala sesuatu. Karena adanya dua pemikiran ini, dibutuhkan sikap saling merendahkan diri satu sama lain. Tak jarang, suami istri mengalami kegagalan untuk menyatukan nilai dan keyakinan hidup.

Ada beberapa faktor mengapa terjadi perbedaan nilai dan keyakinan hidup. Faktor pertama adalah faktor pendidikan atau penanaman nilai dari awal. Setiap anak pada dasarnya membawa serta dalam dirinya faktor-faktor yang telah membentuk dirinya. Kebanyakan faktor itu berasal dari keluarga. Faktor kedua adalah perbedaan tahap perkembangan. Tahap perkembangan ini bisa meliputi tahap perkembangan psikologis maupun kognitif. Perbedaan ini mungkin saja terjadi karena perbedaan pengalaman dan cara memandang pengalaman. Bagi seorang suami, pengalaman anak sakit bisa saja sekedar dipandang sebagai problem kesehatan, dibawa ke dokter dan sembuh. Bagi seorang ibu, problem anak sakit bisa dipandang sebagai problem perawatan, bagaimana mengusahakan supaya kesehatan anak dijaga sejak kecil.

Tidak jarang di dalam keluarga terjadi kekerasan. Kekerasan itu bisa berbentuk kekerasan fisik ataupun psikis. Korban dari kekerasan bisa dialami oleh suami ataupun juga istri. Kekerasan ini seringkali membuat frustasi banyak pasangan hidup. Mereka merasa sudah berkorban sedemikian banyak tetapi tetap sia-sia dan tanpa hasil. Frustasi yang berkepanjangan sering membuat suami istri merasa gagal dalam hidup berkeluarga.

Tidak jarang kehidupan keluarga mengalami ketimpangan. Ketimpangan terjadi karena suami dan istri hanya mementingkan kepentingan diri sendiri, ataupun kepentingan yang menurutnya paling penting. Seringkali suami dan istri gagal melihat permasalahan dari kacamata pasangannya. Akibatnya, pendekatan 
bersifat monolog. Ini seingkali menyebabkan terjadinya pembagian tugas yang tidak fair.

Problem kurang tanggung jawab juga muncul jika tidak ada sikap saling mendukung satu sama lain. Sikap cuek menyebabkan relasi suami istri menjadi lebih berat lagi. Sikap ini bisa terjadi dalam pola relasi suami istri yang terlalu dikotomis antara tugas tanggung jawab suami dan tugas tanggung jawab istri.

Sekarang ini sedang berkembang kecanduan. Kecanduan itu terjadi mulai dari kecanduan rokok, narkoba bahkan yang sampai hari ini sering terjadi adalah kecanduan mobile phone dengan segala macam sosial medianya. Karena kecanduan ini, orang memiliki keterikatan yang tak terpisahkan dengan hal-hal tersebut. Mereka merasa mendapatkan kenikmatan dengan hal-hal tersebut. Mereka merasa bahagia dengan mengkonsumsi rokok, narkoba ataupun juga menggunakan media sosial. Bagaimanapun, kecanduan akan membuat suami dan atau istri tidak fokus pada hidup keluarga, mereka lalu hanya fokus pada kebutuhan diri mereka sendiri.

Di dalam keluarga juga sering terjadi manipulasi relasi. Manipulasi relasi yang dimaksudkan di sini adalah over relasi sehingga keluarga sendiri sering tidak diperhatikan. Sebagai contoh, suami atau istri yang memiliki kedekatan yang begitu tinggi dengan orang tua dan saudaranya. Akibatnya, sering terjadi keluarganya sendiri (keluarga kecilnya) dikalahkan. Manipulasi relasi juga bisa terjadi ketika suami atau istri memiliki relasi yang sangat akrab dengan temantemannya. Keakraban tersebut, kadangkala bisa mengalahkan kewajiban untuk merawat dan mengurus keluarga sendiri.

Tidak jarang keluarga juga diwarnai oleh dengan depresi dan atau stress. Depresi bisa terjadi karena berbagai macam hal. Salah satu yang kadang terjadi adalah sakit yang berkepanjangan atau permasalahan berkepanjangan yang tidak kunjung selesai. Mengalami pengalaman penderitaan entah berupa permasalahan hidup ataupun sakit yang berkepanjangan sering membuat suami atau istri menjadi depresi. Jika suami sakit dan tak kunjung sembuh, depresi bisa terjadi. Jika salah satu dari pasangan mengalami depresi atau stress, pasti pasangannya dituntut untuk menjadi partner yang bisa mendengarkan apa yang mereka rasakan. Sementara itu, pasangan yang mengalami depresi akan lebih kesulitan untuk memerhatikan pasangannya dan juga keluarganya.

\subsection{Problematik Relasi antara Orang Tua dan Anak}

Karen Fingerman's (1996) menyatakan bahwa konflik antara orang tua dan anak adalah konflik yang selalu ada dan persisten sejak anak lahir sampai dengan anak menjadi dewasa, bahkan sampai ketika mereka sudah berkeluarga. Selalu akan ada konflik yang berkelanjutan. Semakin tinggi usia anak, konflik juga semakin berat. Akan tetapi, untungnya konflik antara orang tua dan anak remaja 
itu hanya 5-10\% saja yang memiliki dampak yang berbahaya (Paikof and BrooksGunn 1991). Beberapa konflik agaknya bisa dicatat di sini. Tidak semua konflik dibahas. Hanya beberapa konflik yang rasanya sering terdengar dan terjadi di antara keluarga. Tidak jarang, dalam masa sekolah anak, terjadi konflik antara orang tua dan anak. Pada zaman sekarang ini, ada tendensi di mana orang tua sangat menuntut kepandaian atau kecerdasan anak. Kecerdasan itu diukur dari pencapaian nilai laporan akademik yang bagus. Tidak jarang orang tua rela mengikutkan les ini dan itu supaya anaknya memiliki nilai yang bagus. Orang tua selalu berharap anaknya menjadi pintar, nilainya bagus dan kelak bisa bersekolah di sekolah yang bagus. Tentu ini harapan yang baik karena ingin membekali anak dengan bekal yang baik. Akan tetapi, juga ada kelemahan. Kadang, ada anak yang merasa frustasi dengan berbagai kegiatan akademik yang diikutinya, mulai dari sekolah sampai les ini dan itu. Sejauh les itu diinginkan oleh anak karena kesadarannya, itu menjadi baik. Akan tetapi kalau segala macam les tambahan itu hanyalah paksaan dari orang tua; bahaya besar mengancam.

Tidak jarang juga orang marah dan jengkel kepada anak ketika tahu bahwa anaknya memiliki nilai yang jelek karena tidak memenuhi kriteria ketuntasaan minimal. Kecewa adalah hal yang naluriah. Akan tetapi, sudahkah orang tua bertanya dan merefleksikan tentang kemampuan anak mereka sendiri? Bukankah setiap anak memiliki tingkat dan jenis kecerdasan yang berbeda? Bukankah itu berarti mereka tidak baik untuk dipaksa menguasai sesuatu hal yang bukan menjadi talentanya?

Ketika anak masih kecil, dia akan sangat membutuhkan orang tuanya. Bahkan ada kecenderungan untuk menggantungkan diri pada orang tuanya. Semakin anak bertumbuh besar dan dewasa, ketergantungan itu berkurang dan cenderung menjadi tiada. Anak ingin menjadi pribadi yang dipandang dewasa dan mampu membuat keputusan sendiri. Kalau orang tua tidak sadar akan adanya fase ini, anak akan mengalami ketegangan di dalam dirinya. Dia ingin bergaul dengan teman-temannya, tetapi tidak diberi kepercayaan oleh orang tuanya. Dari pihak orang tua, seringkali ada ketidakpercayaan untuk membiarkan anak tumbuh dan berkembang sesuai dengan kehendaknya. Ketika anak sudah mulai mendekati usia remaja, anak secara umum lebih mudah untuk bergabung atau bersosialiasi dengan teman-temannya. Mereka lebih mudah untuk mengindentifikasikan diri mereka dengan kelompoknya. Ada kecenderungan untuk mulai lepas dari kelurga. Tak jarang di sini terjadi konflik. Orang tua ingin mengajak anak untuk tetap bersama-sama dalam keluarga, sementara anak mulai ingin lepas dari pengaruh orang tua. Kadang hal ini menjadikan ketegangan dan konflik dalam keluarga.

Ketika anak makin tumbuh dewasa, ada keinginan besar dari dalam diri anak untuk menentukan dirinya sendiri. Mereka ingin menentukan mau jadi apa mereka dan bagaimana jalan untuk mencapainya. Bisa jadi jalan yang mereka 
pilih benar, tetapi juga bisa jadi salah. Seringkali di sini muncul konflik antara anak dan orang tua, tentang ingin jadi apa mereka dan bagaimana mencapainya.

Pada masalah yang lebih berat, sering terjadi anak mengalami kecanduan. Ini juga mimbulkan konflik dalam keluarga. Kecanduan bisa bermacam-macam. Mulai dari kecanduan rokok, obat terlarang dan psikotropika, narkoba dan yang paling modern adalah kecanduan media sosial dan atau handphone. Masingmasing kecanduan memiliki gradasi masing-masing. Akan tetapi, bagaimanapun juga, kecanduan membuat anak tidak mudah bersosialisasi. Mereka lebih asyik dengan diri mereka dan pemenuhan kebutuhan mereka sendiri. Ketegangan dalam hal ini bisa menjadi berat.

Tidak jarang bisa dilihat bahwa anak juga mengalami problem kriminal dan moral. Ada yang tingkatnya rendah sampai dengan tingkat yang berat. Dalam modus kriminal, anak bisa saja sudah mulai belajar mencuri. Dalam modus moral, anak bisa saja sudah mulai berpacaran dan mengarah pada seks bebas. Dua hal ini rasanya makin berkembang hari-hari ini.

Rasanya keluarga sudah memberikan yang terbaik, tetapi senyatanya anak jatuh dalam seks bebas sehingga hamil. Keluarga sudah mewanti-wanti dengan sungguh-sungguh, tetapi anak ternyata masuk dalam kelompok pencuri. Masih banyak masalah lagi di bidang ini. Keluarga bisa mengalami konflik dalam masalah-masalah seperti ini. Banyak orang tua yang frustasi ketika masalahmasalah seperti ini bermunculan.

Memang harus disadari bahwa membangun hidup berkeluarga bukanlah menyelesaikan masalah. Pernikahan dan terjadinya keluarga adalah sebuah konsekuensi dari cinta yang tulus antara seorang pria dan seorang wanita. Namun sejatinya, cinta saja tidak cukup. Suami istri adalah persekutuan hidup bersama. Persekutuan yang dilandasi oleh komitmen. Persekutuan tersebut melanjutkan cinta yang tulus yang berkembang di antara mereka.

Ketika keluarga mulai beranjak, makin jelas bahwa konflik, ketegangan, rasa sakit juga muncul di dalam hidup keluarga kristiani. Ini adalah hal yang tidak bisa dipungkiri. Pertanyaan mendasar, adakah damai di tengah keluarga? Bisakah damai berkembang di dalam keluarga? Berkaitan dengan tahun kerahiman ini, bisakah wajah Kerahiman Allah bersinar di tengah keluarga? Keluarga-keluarga Kristiani, di tengah berbagai masalah yang ada dan mendera, masih bolehkan memandang cerahnya Kristus yang bersinar? Tentu dalam iman, harapan dan kasih Allah sendiri, masih ada sinar terang di dalam keluarga Kristiani. 


\section{MENAMPAKKAN WAJAH KERAHIMAN ALLAH DI TENGAH KELUARGA KRISTIANI DEWASA INI}

Wajah kerahiman Allah senyatanya bersinar untuk seluruh keluarga Kristen. Apapun permasalahan hidup keluarga kristiani, apapun problem yang mendera, apapun duka derita yang dialami oleh anggota-anggota keluarga Kristiani, sesungguhnya wajah Kerahiman Allah bersinar untuk setiap keluarga-keluarga Kristiani. Allah yang pengampun, Allah yang mengasihi, Allah yang menyembuhkan, Allah yang mengampuni, Allah yang tidak pernah meninggalkan dan seterusnya-dan seterusnya, itulah wajah Allah yang saat ini sedang menyapa keluarga-keluarga Kristiani. Yakinlah bahwa Allah tidak tinggal diam. Allah masuk dan terlibat bersama dalam kehidupan dan pergulatan setiap keluarga Kristiani.

Kerahiman Allah adalah cara pandang yang terbalik. Ini harus dipahami dengan tegas dan jelas oleh setiap orang Kristen. Allah tidak lagi pertama-tama berbicara tentang tuntutan keadilan dan kesucian. Allah tidak lagi menuntut keadilan di tempanya yang pertama dan utama.

Allah pertama-tama justru datang kepada manusia yang senyatanya telah berdosa. Allah berinkarnasi untuk mendatangi manusia yang berdosa. Tanpa ada syarat tanpa ada privilese. Kerajaan Allah sungguh datang di dunia menjumpai setiap pribadi manusia. Dalam konsep Allah yang adil, maka Allah bertugas untuk menghukum manusia. Siapa yang berbuat baik maka dia akan mendapatkan balasan yang baik. Siapa yang berbuat jahat maka akan mendapatkan hukuman.

Itu adalah konsep yang sudah usang dan digantikan oleh warta penebusan Kristus sendiri. Allah tidak pertama-tama datang membawa pedang keadilan untuk menghukum manusia. Karena kasihNya, Allah justru mendatangi manusia yang berdosa, mengampuninya, dan membawanya pada hidup yang baru. Inilah cara pandang yang baru. Cara pandang yang terbalik. Tetapi, yakinlah bahwa pengampunan, kasih, kemurahan, dan kerahiman justru akan membuahkan pertobatan (metanoia). Tuntutan keadilan, justru tidak akan membawa pada pertobatan.

Cara pandang ini menawarkan cara hidup yang lain sema sekali. Karena kita sudah dipanggil dan ditebus, tinggal bagaimana kita hidup sebagai anak-anak yang sudah ditebus. Karena kita sudah diampuni, tinggal bagaimana kita hidup tanpa jatuh ke dalam dosa lagi. Karena kita telah ditemukan oleh Allah, bagaimana kita tidak hilang lagi dari rangkulan kasih Allah. Inilah kerahiman Ilahi yang sedang memancar. Menjadi murid, menjadi garam, mewartakan kasih dan sebagainya adalah cara untuk menjawab Allah yang tanpa syarat telah lebih dahulu menyapa manusia.

Pertanyaan selanjutnya adalah bagaimana senyatanya menghidupkan wajah kerahiman Allah di tengah keluarga Kristiani. Pada pokok yang pertama pantas 
dicatat bahwa wajah kerahiman Allah itu terpancar melalui anggota-anggota keluarga. Setiap anggota keluarga pada dasarnya adalah wajah kerahiman Allah. Bukankah setiap manusia diciptakan oleh Allah secitra dengan Allah, menurut rupa dan gambar Allah? Ini adalah adagium yang tak terbantahkan. Artinya, jangan berharap ada kerahiman Allah di tengah keluarga kristiani kalau masingmasing dari anggota keluarga tidak memancarkan wajah kerahiman itu. Wajah kerahiman Allah senyatanya sudah hadir, hanya saja masih tersembunyi di dalam topeng kita masing-masing. Beranikah anggota keluarga melepaskan topengnya masing-masing supaya wajah kerahiman Allah sungguh memancar?

Karena Allah telah mengasihi dan berbelas kasih kepada kita semua. Mari kita wartakan kasih dan belas kasih Allah itu dalam keluarga kita. Ketika ada anggota keluarga yang mengalami kesakitan, biarlah wajah kasih dan belas kasih Allah memancar. Karena Allah telah mengampuni dan menebus dosa umat manusia dengan cuma-cuma, biarlah pengampunan juga diberikan untuk setiap anggota keluarga yang mungkin berbuat salah dan melakukan tindan dosa. Pengampunan Allah sungguh tak terhingga. Karena Allah telah melepaskan kita dari kuk perhambaan dosa yang berat. Biarlah warta pembebasan juga terjadi di tengah keluarga. Biarlah anggota keluarga mendapatkan pembebasan dari berbagai tuntutan-tuntutan yang justru memberatkan dan membuat anggota keluarga mengalami kesakitan. Karena Allah telah menerima kembali mereka yang hilang dan bahkan mencari yang tersesat, marilah menemukan dan mencari kembali anggota keluarga kita yang mungkin sampai hari ini tidak pernah kembali. Mungkin ada luka dan sakit hati karena adanya konflik atau tindakan

salah. Pengampunan, pencarian, dan penerimaan kembali adalah kunci untuk pendamaian. Karena Allah telah memberikan diriNya tanpa syarat untuk seluruh umat manusia, biarlah kita pun memberikan diri tanpa syarat untuk setiap anggota keluarga kita. Layanilah satu sama lain tanpa syarat, tanpa privilese. Dalam pelayanan satu sama lain pasti ada kasih. Basuhlah kaki anggota keluarga sebagaimana telah diajarkan oleh Yesus dalam perjamuan malam terakhir. Di sanalah terjadi sikap melayani. Melayani anggota keluarga, bukan memerintah.

\section{KESIMPULAN}

Wajah kerahiman Allah telah terpancar di dalam keluarga-keluarga Kristiani. Adalah kebutuhan bagi setiap anggota keluarga untuk mengalami Allah yang maharahim. Hanya dalam pengalaman itu anggota-anggota keluarga bisa menampakkan wajah kerahiman Allah. Untuk bisa menjadi agen-agen kerahiman Allah, tidak ada cara lain untuk setiap anggota keluarga mengalami dan merefleksikan diri menerima kerahiman itu. Setiap anggota keluarga perlu mengalami dan menyadari. Ruang-ruang pengampunan terbuka lebar untuk setiap 
anggota keluarga. Ruang-ruang rahmat terbuka untuk setiap anggota keluarga Kristiani yang ingin terlibat.

\section{DAFTAR PUSTAKA}

. 2004. Alkitab. Ende: Percetakan Arnoldus Ende.

Brooks-Gunn, J., \& Petersen, A. C. (Eds.). 1991. The emergence of depression and depressive symptoms during adolescence. Journal of Youth and Adolescence, Volume 20, Issues 1 \& 2.

Fingerman, Karen L., 2016. Sources of Tension in the Aging Mother and Adult Doughter Relationship.

Fransis, 2016. Bull Of Indiction of The Extraordinary Jubilee of Mercy: Misericordiae Vultus.

Paulus, Yohanes II.1993. Familiaris Consortio. Jakarta: Departemen Dokumentasi dan Penerangan KWI.

-------, 2017. Amoris Laetitiae. Jakarta: Departemen Dokumentasi dan Penerangan KWI.

Suhardi, Aloysius. 2011. "Pastoral Keluarga: Merevitalisasi Peranan Keluarga Kecil dalam Kehidupan Gereja” dalam Keluarga Kristiani dalam Badai Globalisasi. Madiun: Wina Press.

Wilhelmus, Ola Rongan. 2011. Keluarga Kristiani Merespon Globalisasi dalam Keluarga Kristiani dalam Badai Globalisasi. Madiun: Wina Press.

Worthington, Everett L.1989, Marriage Counseling: A Christian Approach to Counseling Couples. US: Intervarsity Press 